PRINT ISSN 1119-8362

Electronic ISSN 1119-8362
Full-text Available Online at

https://www.ajol.info/index.php/jasem

http://ww.bioline.org.br/ia
J. Appl. Sci. Environ. Manage.

Vol. 24 (12) 2017-2025 December 2020

\title{
Socio-Ecological impacts of Water Hyacinth, Eichhornia crassipes (MART.) in Lake Tana, Gulf of Gorgora, Ethiopia
}

\section{FLIPOS ENGDAW}

\author{
Department of Biology, College of Natural and Computational sciences, University of Gondar, P.O. BOX 196, Ethiopia \\ AuthorEmail: flipos.engdaw@uog.edu.et; d.flipos2002@gmail.com;.Tel.+251974464090
}

\begin{abstract}
Water hyacinth is one of the aggressive alien aquatic macrophyte threatening biodiversity, economic development and human wellbeing. Currently, the macrophyte has invaded Lake Tana and its catchment causing several socio-ecological impacts. So far, there is limited information on socio-ecological impact of water hyacinth in Lake Tana specifically gulf of Gorgora. Therefore, the main aim of this study was to assess socio-ecological impact of water hyacinth in Lake Tana gulf of Gorgora, located in North West of Ethiopia from November 2019 to January 2020. Two sampling sites (infested and non-infested) were identified based on infestation of water hyacinth. A total of 30 water and 12 water hyacinth samples were collected with a survey of 50 individuals. Results revealed that water quality, phytoplankton diversity, fishing, navigation, health condition of local people, recreational and aesthetic value were impacted negatively due to infestation. Conversely, higher accumulation of toxic heavy metals and dissolved metallic ions in the root, stem and leaf of the macrophyte impacted positively. Infestation of the macrophyte significantly affected water quality and species diversity of Lake Tana. In the infested site; DO (3.3 to 4.5), SRP ( 0.012 to $\left.0.023 \mathrm{mg} \mathrm{L}^{-1}\right)$, TP $(0.24$ to $0.28 \mathrm{mg} \mathrm{L}$ $\left.{ }^{1}\right), \mathrm{NO}_{3}-\mathrm{N}\left(0.74\right.$ to $\left.0.97 \mathrm{mg} \mathrm{L}^{-1}\right)$ and $\mathrm{TN}\left(2.1\right.$ to $\left.3.2 \mathrm{mg} \mathrm{L}^{-1}\right)$ were significantly $(\mathrm{p}<0.01)$ lower than non-infested site. Generally, infestation of water hyacinth negatively impacted the society and the ecology in Lake Tana catchment. Therefore, continuous monitoring and management of the macrophyte is required.
\end{abstract}

DOI: https://dx.doi.org/10.4314/jasem.v24i12.2

Copyright: Copyright $(\mathcal{C} 2020$ Flipos. This is an open access article distributed under the Creative Commons Attribution License (CCL), which permits unrestricted use, distribution, and reproduction in any medium, provided the original work is properly cited.

Dates: Received: 11 October 2020; Revised: 13 November 2020; Accepted: 24 November 2020

Keywords: Heavy metal, infestation, Macrophyte, nutrient, phytoplankton

Taxonomically, water hyacinth, Eichhornia crassipes (Mart.) belongs to the family Pontederiaceae, which has been included in the order Commelinales. The family is represented by eight genera where Eichhornia alone has eight species originated in the Amazon basin of South America (DiTomasa and Kyser, 2013; Worku and Sahile, 2018). Water hyacinth is a perennial, herbaceous, free-floating aquatic plant in open water but often rooted in moist mud along the banks of rivers, lakes, and impoundments (Admas et al., 2017; Worku and Sahile, 2018; Dersseh et al., 2019). Vegetative structure of the hydrophyte consists of a rosette of six to ten leaves attached to a rhizome with a welldeveloped fibrous root system where reproduction can be both sexual and asexual (Jones et al., 2018). Since the late 1800's anthropogenic activities play a significant role in the spreading of the plant for ornamental purpose due to the inflorescences of flowers (Admas et al., 2017; Dersseh et al., 2019; Dersseh et al., 2020). Water hyacinth is an invasive species that has invaded freshwater systems in over 50 countries on five continents. According to recent climate change models, its distribution may expand into higher latitudes as temperatures rise (Hellmann et al., 2008; Rahel and Olden, 2008). The species is also prevalent in tropical and sub-tropical water bodies where water nutrient concentrations are often high due to agricultural runoff, deforestation and insufficient wastewater treatment (Wondimu, 2016; Goshu and Aynalem, 2017; Gebremedhin et al., 2018). However, there is no clear record of how, why and when water hyacinth was introduced to water bodies outside of its native range. In Africa, the species was first introduced in Egypt between 1879 and 1882 and then observed in White Nile in 1958; consequently, it was infested in the rest of Nile River and other East African regions aided through flooding and boat transport (Yifru et al., 2007; Dersseh et al., 2020). In Ethiopia, infestation of water hyacinth was first reported in 1965 in Lake Koka and its main tributary River Awash (Yifru et al., 2007; Admas et al., 2017; Dersseh et al., 2019). Although there is no clear evidence on the causes and sources of water hyacinth infestation into non-native Ethiopian inland water bodies, in 2011 the species was highly infested in the highland lakes including Lake Tana which is the main source of Blue Nile (Wondie et al., 2012; Dersseh et al., 2019). Both 
accidental (through flood, boat transport and fishing gears) and intentional (due to its ornamental and aesthetical value) introduction of the species are considered as the main routs of infestation into Ethiopian highland lakes (Dersseh et al., 2020). Once the species is established, it has a strong ecological and socio-economic impacts in the vicinity. Ecologically, its infestation in the form of floating dense mat leads to drastic deterioration of water quality such as decline in the amount of dissolved nutrients, temperature, $\mathrm{pH}$ and reduced dissolved oxygen in the water column leading to mass destruction of the fish fauna and decline in net primary production of the system (Chapungu et al., 2018; Dersseh et al., 2020; Enyew et al., 2020). Moreover, it affects fishing, high accumulation of organic matter and higher biological oxygen demand, less phytoplankton abundance and diversity, outcompete other riparian and aquatic vegetations. Socio-economically, it affects boat transport, navigation, recreational value of aquatic systems, affect water flow and mechanical damage to hydropower systems (Chapungu et al., 2018; Enyew et al., 2020). Recent reports from Ethiopian inland water bodies make known that, an estimate of US\$100,000 was invested for eradication purpose from 2000 to 2013 (Dersseh et al., 2019). Similarly, fishing activities where most people depend on becomes hard due to transportation and stock decline caused by absence of fish breeding ground and fish feed (less abundance of phytoplankton) (Wondie et al., 2012). Furthermore, decline in species abundance and diversity of other native aquatic macrophytes, invading agricultural lands and cause water quality deterioration. In contrary, water hyacinth has also an inevitable role in phytoremediation of excess nutrient and heavy metal concentrations (Kabeer et al., 2013; Jones et al., 2018). Apart from few researches focusing on land cover, control and management of water hyacinth (Yifru et al., 2007; Admas et al., 2017; Dersseh et al., 2019; 2020), there is diminutive information depicting its socio-ecological impacts in relation to phytoplankton, other aquatic macrophytes and water quality in Lake Tana catchment. Therefore, the main aim of the present study is to investigate the socio-ecological impacts of water hyacinth in Lake Tana specifically at the gulf of Gorgora.

\section{MATERIALS AND METHODS}

Study area: Lake Tana is the largest lake of Ethiopia located in the North West part between $12^{0} 10^{\text {'North }}$ and $37^{\circ} 23^{\prime}$ East with an altitude of 1800 (Figure 1). The total surface area of the lake reaches about $3,050 \mathrm{~km}^{2}$ with maximum and mean depths of $14 \mathrm{~m}$ and $8 \mathrm{~m}$ respectively. The water from the lake is used for hydropower generation, fishery production, irrigation, water supply and waste disposing site. Lake Tana is the main source of Blue Nile River with Oligotrophic character. (Wondim, 2016; Gebremedhin et al., 2018). The lake is registered by UNESCO as world's heritage of biodiversity. Apart from the endemic fauna and flora, presence of ancient monasteries in the highlands and historical sites make the lake most precious natural resource serving as heritage (Wondim, 2016; Gebremedhin et al., 2018). However, the recent huge infestation of exotic water hyacinth causes a serious socio-ecological problem around the lake and its catchment (Goshu and Aynalem, 2017).

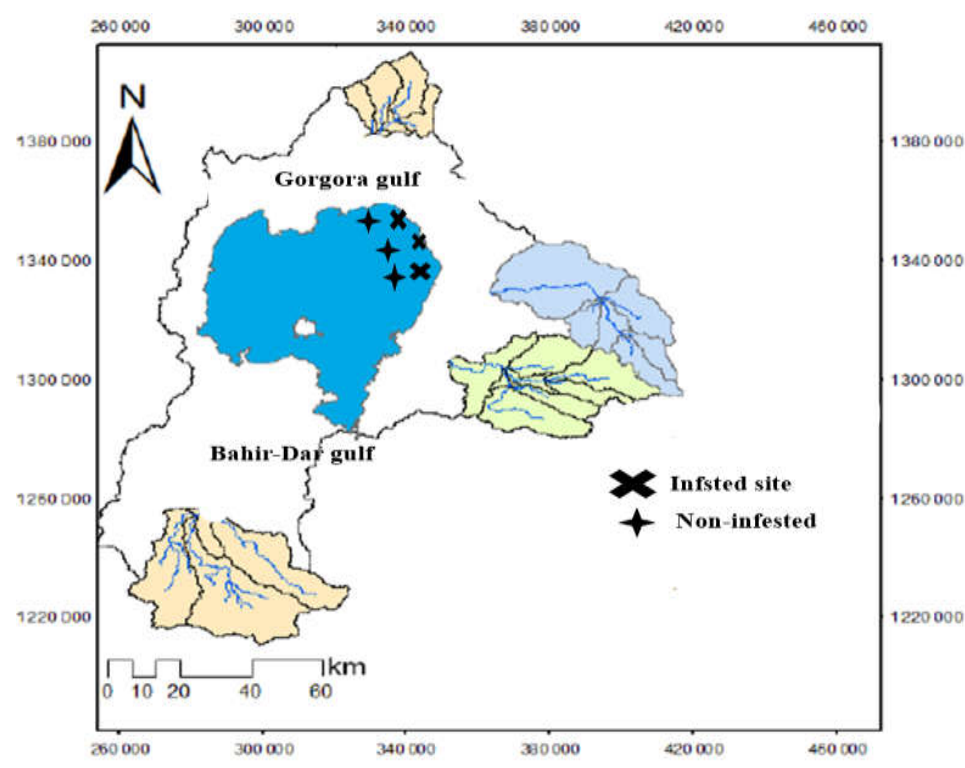

Fig 1. Map of study area indicating sampling sites

FLIPOS ENGDAW 
Sampling and Measurements: To assess the socioecological impacts of water hyacinth in Lake Tana, gulf of Gorgora and its catchment, two sampling sites; areas covered with water hyacinth and without water hyacinth were selected purposively based on the distribution pattern of the hydrophyte. In each sampling site, three different sampling points were located to collect water and macrophyte samples for the analysis of water quality parameters including heavy metals and plankton abundance and distribution.

Water quality measurement and analysis: In-situ physico-chemical parameters of water such as temperature (Temp), $\mathrm{pH}$, dissolved oxygen (DO), electrical conductivity (EC) were measured using multi meter probe (HQ40d, model 10115) and turbidity (Tur) using (Apera TN 400) in triplicate prior to collecting water and macrophyte samples. A total of 30 water samples were collected 5 times every 10 days from $15^{\text {th }}$ November 2019 to $7^{\text {th }}$ January 2020. During sampling, replicate water samples were collected around Achera, a shore with huge infestation of water hyacinth and around Gorgora gulf, $10-50 \mathrm{~cm}$ deep from the surface on each sampling site. All collected replicate water samples were homogenized in a single container to have one composite sample. It was then filtered through $0.47 \mu \mathrm{m}$ pore size glass fiber filters (Whatman GFF) using $300 \mathrm{ml}$ vacuum hand filter and collected in a pre-cleaned (using $10 \% \mathrm{H}_{2} \mathrm{SO}_{4}$, rinsed with distilled water) plastic bottles for nutrients such as soluble reactive phosphorus (SRP) nitrate $\left(\mathrm{NO}_{3}-\mathrm{N}\right)$, cations $\left(\mathrm{Ca}^{2+}, \mathrm{Mg}^{2+} \mathrm{K}^{+}\right)$and heavy metals $(\mathrm{Cr}, \mathrm{Cd}, \mathrm{Zn}$, $\mathrm{Cu}, \mathrm{Pb}$ ) analysis whereas unfiltered water samples were collected for total phosphorus (TP) and total nitrogen (TN). Both filtered and unfiltered water samples were kept in a cool box till transported to laboratory. For the analysis of nutrients, heavy metals and cations in the water and the macrophyte samples, standard methods outlined by American public health association (APHA, 1999) were adopted.

Macrophyte sampling: A total of 12 different $E$. crassipes macrophyte samples were collected once from site with huge infestation, which is at Achera site of Lake Tana. The collected macrophyte were sorted into leaf, stem and root parts using stainless surgical blade. The different parts were quickly wrapped with polyethylene plastic bags and kept in a cool box till transported to laboratory for analysis.

Sampling for phytoplankton biodiversity: Phytoplankton frequency of occurrence and percentage abundance was determined through identifications and enumeration of plankton species by collecting water samples from sampling sites. The collected water samples were preserved with lugol's solution and identification was done using Olympus compound microscope (CX21FS1) using freshwater algae book (Tarekegn et al., 2012).

Qualitative data collection: To assess socio-economic impact of water hyacinth in the vicinity, semi structured interview, questioners and personal observations were employed to elicit facts from respondents. The interview included experts and district environmental officers focusing on the socioeconomic impact of water hyacinth in the vicinity. A total of 50 questionnaires were distributed to collect data on social and ecological impacts of water hyacinth.

Data Analysis: The data recorded from both field and laboratory analysis was summarised using descriptive statistics such as mean, percentage and standard deviation. After the data was checked for normality using Shapiro-Wilk test, both parametric and nonparametric ANOVA was computed to compare the spatial variation in physico-chemical, nutrient and concentrations of heavy metals. Occurrence and percentage abundance of phytoplankton was determined following the method developed by (Bowen, 1983).

$$
F i=\frac{(N i * 100)}{N}
$$

Where, $\mathrm{Fi}=$ Frequency of occurrence of the i species in the sample; $\mathrm{Ni}=$ Number of slides examined in which the $\mathrm{i}$ item is found and $\mathrm{N}=$ is total number of slides with plankton in the sample.

$$
\% \text { Abundance }=\frac{\left(V_{\text {sap }}\right)}{\mathrm{V}_{T}} * 100
$$

Where Vsap = volumetric estimation of the sap; VT= total volume of phytoplankton

\section{RESULTS AND DISCUSSION}

Physicochemical water quality parameters: In the present study, it was established that water hyacinth infestation significantly affects some water quality parameters (Table 1). Most of the in-situ measured physico-chemical parameters such as Temp, $\mathrm{pH}, \mathrm{DO}$ and EC showed a significant spatial variability $(\mathrm{p}<$ 0.01 ) and can also influence on sorption, precipitation and solubility of nutrients within the water column ( $\mathrm{Li}$ et al., 2013; Wondimu, 2016; Akale et al., 2018). Maximum temperature measured at both infested and non-infested sites was within the normal environmental temperature range of $21-27{ }^{\circ} \mathrm{C}$ (Abebe and Kebede, 2017) and suitable for growth of aquatic 
plants. However, the relative lower temp measured at the infested site could be attributed to the canopy cover of the water hyacinth which form a dens mat. A slightly alkaline $\mathrm{pH}$ range of $8.2-8.7$ was measured in both infested and non-infested sites, and the value is still within the limit of different guidelines for drinking, bathing, livestock watering and irrigation (WHO, 2011; USEPA, 2011). The finding corroborates with previous findings from same water body (Wondimu, 2016; Dersseh et al., 2019). DO concentration showed significant spatial difference $(\mathrm{p}$ $<0.01)$ between infested and non-infested sites ranging from 3.31 to $8.4 \mathrm{mg} \mathrm{L}^{-1}$. Lower DO value measured at the infested site could be attributed to the severe anthropogenic influence which increase the entry of organic matter from surface runoff and agricultural fields. Similarly, decomposition of water hyacinth plant and other detritus material could lead to decline in DO concentration (Wondie et al., 2007; Strokal et al. 2016). In contrary, higher DO measured in the open water could possibly be due to production by phytoplankton, low rate of decomposition and atmospheric diffusion (Engdaw and Subramanian, 2015). EC measured in the infested and non-infested site ranged between $52-58 \mu \mathrm{s} / \mathrm{cm}$ and $123-142 \mu \mathrm{s} / \mathrm{cm}$, respectively.

Table 1. Physicochemical water quality parameters from water hyacinth infested and non- infested area of Lake Tana, gulf of Gorgora

\begin{tabular}{llll|lll}
\multicolumn{9}{c}{$(\mathrm{n}=30)$} \\
\hline Parameter & \multicolumn{2}{c|}{ Infested area (Mean \pm SD) } & \multicolumn{3}{c}{ Non infested area (Mean \pm SD) } \\
& Site 1 & Site 2 & Site 3 & Site 1 & Site 2 & Site 3 \\
\hline Temperature & & & & & & \\
$\left({ }^{\circ} \mathrm{C}\right)$ & $23.9 \pm 0.97$ & $23.8 \pm 1.22$ & $23.6 \pm 1.76$ & $26.7 \pm 1.09$ & $25.2 \pm 0.89$ & $25.5 \pm 0.81$ \\
pH & $8.28 \pm 0.01$ & $8.35 \pm 0.1$ & $8.42 \pm 0.65$ & $8.61 \pm 0.21$ & $8.67 \pm 0.23$ & $8.7 \pm 0.12$ \\
Turbidity (mg/l) & $52 \pm 5.59$ & $62 \pm 4.32$ & $47 \pm 3.2$ & $74 \pm 1.2$ & $82 \pm 0.00$ & $76 \pm 0.1$ \\
EC $(\mu \mathrm{S})$ & $58 \pm 2.23$ & $52 \pm 2.45$ & $57 \pm 2.11$ & $123 \pm 1.67$ & $142 \pm 1.72$ & $127 \pm 1.32$ \\
DO (mg/l) & $3.31 \pm 0.69$ & $4.34 \pm 0.39$ & $4.55 \pm 0.14$ & $7.9 \pm 0.23$ & $8.2 \pm 0.20$ & $8.4 \pm 0.88$ \\
TP $(\mathrm{mg} / 1)$ & $0.27 \pm 0.65$ & $0.24 \pm 0.43$ & $0.28 \pm 0.35$ & $0.16 \pm 0.16$ & $0.13 \pm 0.21$ & $0.15 \pm 0.18$ \\
$\mathrm{SRP}(\mathrm{mg} / \mathrm{l})$ & $0.012 \pm 0.01$ & $0.015 \pm 0.1$ & $0.023 \pm 0.0$ & $0.032 \pm 0.1$ & $0.038 \pm 0.2$ & $0.041 \pm 0.01$ \\
$\mathrm{TN}(\mathrm{mg} / \mathrm{l})$ & $2.82 \pm 2.3$ & $3.2 \pm 1.2$ & $2.1 \pm 1.41$ & $1.7 \pm 1.51$ & $1.8 \pm 1.11$ & $1.9 \pm 1.43$ \\
$\mathrm{NO}_{3}-\mathrm{N}(\mathrm{mg} / \mathrm{l})$ & $0.8 \pm 0.23$ & $0.97 \pm 0.18$ & $0.74 \pm 0.13$ & $1.1 \pm 0.12$ & $1.3 \pm 0.89$ & $1.1 \pm 0.77$ \\
\hline
\end{tabular}

The possible justification for the lower $\mathrm{EC}$ at the infested area could be ascribed to absorption of metal ions by water hyacinth itself, other aquatic macrophytes and might also be due to adsorption by sediment (Wondimu, 2016). However, the higher EC at site 2 could be associated with low absorption capacity of phytoplankton on dissolved metal ions or due to increased domestic and industrial effluent via tributary rivers. The highest recommended values for EC in natural water bodies is $2500 \mu \mathrm{S} / \mathrm{cm}$ and values from this study was within the range (WHO 2011). In aquatic systems, there is a strong association between nutrient influx and anthropogenic activities, agricultural runoff, domestic and industrial wastes (Hou et al., 2013). In this study, Concentrations of nutrients measured from both infested and noninfested area indicated significant spatial difference $(\mathrm{p}$ $<0.01)$ between sampling sites. In Table 1, the highest $\mathrm{TP}\left(0.28 \mathrm{mg} \mathrm{L}^{-1}\right)$ was measured at the infested site and the lowest value was noted at non-infested site $(0.13$ $\left.\mathrm{mg} \mathrm{L}^{-1}\right)$. Conversely, the highest SRP $\left(0.041 \mathrm{mg} \mathrm{L}^{-1}\right)$ concentrations was measured at non infested site. Phosphorus influx from catchment to the lake via tributaries and runoffs might be either in particulate or dissolved forms (Hou et al., 2013; Dersseh et al. 2019). The lower SRP concentration observed at water hyacinth infested site might be due to uptake by water hyacinth itself, other macrophytes, bacteria and phytoplankton communities (Gerhardt et al., 2010).
On the other hand, higher SRP at non-infested area could be attributed to release of $\mathrm{PO}_{4}$ to the environment from decomposition and anoxic reduction of phosphorus containing complex compounds (Gerhardt et al., 2010). Apart from the anthropogenic and allochthonous sources of SRP, autochthonous supplies from animal excretion and bacterial decomposition of the non-reactive forms play significant role (Strokal et al., 2016). The highest TP at the infested site might also be due to dead and decomposed part of the macrophyte or due to resuspension of particulate forms by wave (Dersseh et al., 2019). Contributions of agricultural fertilizers specifically urea and DAP applied for crop production around the lake shore of Achera site together with dissolved organics and colloidal particles to TP concentration is also a great importance (Gerhardt et al., 2010; Hou et al., 2013). $\mathrm{TN}$ and $\mathrm{NO}_{3}-\mathrm{N}$ concentrations in the present study followed same trend as TP and SRP where higher concentrations of TN (3.2 $\left.\mathrm{mg} \mathrm{L}^{-1}\right)$ was noted at site with infested site and lower concentrations $\left(1.7 \mathrm{mg} \mathrm{L}^{-1}\right)$ were measured at non-infested sites. Maximum $\mathrm{NO}_{3}-\mathrm{N}\left(1.3 \mathrm{mg} \mathrm{L}^{-1}\right)$ was recorded at non-infested site and the minimum $(0.74$ $\mathrm{mg} \mathrm{L}^{-1}$ ) was measured at infested site (Table 1). The flux and dynamics of $\mathrm{TN}$ and $\mathrm{NO}_{3}-\mathrm{N}$ in aquatic system is extremely influenced by riparian vegetation and concentrations of DO (Strokal et al., 2016). The lower $\mathrm{NO}_{3}-\mathrm{N}$ at the infested site possibly be attributed to

\section{FLIPOS ENGDAW}


absorption by the highly infested water hyacinth and other aquatic macrophytes. It could also be transformed to other forms of nitrogen due to the lower concentration of DO recorded at the infested site (Sarneel et al., 2010). Generally, concentration of TN higher than $0.3 \mathrm{mg} \mathrm{L}^{-1}$ is enough to cause eutrophication in aquatic systems (Tibebe et al., 2018). Therefore, the current huge infestation of water hyacinth as well as future eutrophication of Lake Tana is expected.

Phytoplankton distribution: A total of 34 phytoplankton genera/species belonging to 4 higher taxonomic groups such as Cyanophyta (blue green), Chlorophyta (green algae), Bascillariophyta (diatom) and Euglenophyta were identified (Table 2). In the non-infested site, of all taxonomic genera, members of Chlorophyta were the most abundant groups constituting 13 species $(38.2 \%)$ of the total phytoplankton recognized followed by Bascillariophyta which comprise 10 species $(29.4 \%)$ and Cyanophyta embrace 9 species (26.5\%). However, Euglenophyta was found to be the least abundant group that constitutes the remaining 2 species (5.9\%) (Table 2 and 3). Both internal and external environmental drivers including any spatiotemporal variability in abiotic and biotic factors together with excess nutrient enrichment causes loss of phytoplankton biodiversity in aquatic systems (Villamagna and Murphy, 2010; Gao et al., 2017). Apart from the dense assemblage of emergent macrophytes such as water hyacinth that notably affect phytoplankton diversity and richness, most limiting factors for growth and abundance of phytoplankton includes light, temperature, concentrations of nutrients (specifically Nitrogen and Phosphorus) and biological interactions such as competition and predation by zooplankton and fish (Engdaw, 2014; Gao et al. 2017). Finding of the current study disclosed a significant spatial variation $(p<0.01)$ in abundance and distributions of phytoplankton underlying the effect of water hyacinth in the infested site. The lower number of species recorded in the infested site (Table 2 and 3 ) could possibly be ascribed to the low light incident striking the water surface availability which is blocked by the canopy cover of the macrophyte. Thus, it hampers rate of photosynthesis resulting in limited growth and reproduction (Dersseh et al., 2020).

Poor nutritional conditions of phytoplankton caused by water hyacinth due to effective nutrient absorption might also inhibit the growth of algal communities. According to the recent findings of Gao et al. (2017); Worku and Sahile (2018), water hyacinth can produce a bioactive compound using its fibrous that inhibit growth of algae and other emergent macrophyte around its vicinity. Therefore, the areal coverage and distribution structure of water hyacinth in Lake Tana plays a significant role in determining the community structure of phytoplankton, zooplankton fish and other aquatic organisms, since any shift in primary production at base of food chain brings habitat destruction and strongly alter energy flow (Villamagna and Murphy, 2010).

\begin{tabular}{|c|c|c|c|c|}
\hline Phytoplankton Taxa & $\begin{array}{l}\text { Infested Site } \\
\text { Occurrence }\end{array}$ & Abundance & $\begin{array}{l}\text { Non-infested site } \\
\text { Occurrence }\end{array}$ & Abundance \\
\hline \multicolumn{5}{|l|}{ Cyanophyceae } \\
\hline Anabaena & 17 & 2.1 & 20 & 1.4 \\
\hline Aphanocapsa & --- & --- & 18 & 1.7 \\
\hline Chroococcus & 12 & 0.9 & 42 & 8.8 \\
\hline Coelosphaerium & 23 & 2.1 & 48 & 10.8 \\
\hline Cylinderospermosis & --- & --- & 35 & 3.1 \\
\hline Lyngbya & --- & --- & 26 & 7.3 \\
\hline Microcystis & --- & --- & 48 & 15.4 \\
\hline Oocystis & 23 & 0.7 & 24 & 0.9 \\
\hline Planktolyngby & --- & --- & 32 & 5.2 \\
\hline \multicolumn{5}{|l|}{ Chlorophyceae } \\
\hline Ankistrodesmus & 14 & 0.4 & 18 & 1.2 \\
\hline Botryococcus & --- & --- & 38 & 4.7 \\
\hline Chlamydomonas & 12 & 0.2 & 17 & 1.7 \\
\hline Chlorella & --- & --- & 23 & 2.4 \\
\hline Closterium & 17 & 0.4 & 23 & 2.1 \\
\hline Cosmarium & --- & --- & 12 & 1.5 \\
\hline Crucigenia & --- & --- & 24 & 3.1 \\
\hline Oscilatoria & 15 & 1.4 & 17 & 1.9 \\
\hline Pediastrum & -- & --- & 11 & 0.5 \\
\hline Spirogyra & 16 & 0.7 & 26 & 2.4 \\
\hline Ulothrix & 12 & 1.1 & 11 & 0.7 \\
\hline Volvox & 17 & 1.4 & 28 & 3.3 \\
\hline Zoochlorela & --- & --- & 14 & 0.4 \\
\hline
\end{tabular}


Table 3. Frequency of occurrence and volumetric abundance of Bacillariophyceae and Euglenophyceae communities identified in water hyacinth infested and non-infested sites

\begin{tabular}{|c|c|c|c|c|}
\hline Phytoplankton Taxa & \multicolumn{2}{|l|}{ Infested Site } & \multicolumn{2}{|c|}{ Non-infested site } \\
\hline \multicolumn{5}{|l|}{ Bacillariophyceae } \\
\hline Anomoneies & 14 & 1.2 & 26 & 3.1 \\
\hline Cyclotella & 16 & 1.7 & 37 & 3.9 \\
\hline Cymbella & --- & --- & 28 & 1.0 \\
\hline Fragilaria & 14 & 1.1 & 27 & 1.1 \\
\hline Melosira & -- & -- & 27 & 2.8 \\
\hline Navicula & 17 & 0.5 & 18 & 0.5 \\
\hline Nitzschia & 26 & 1.2 & 24 & 1.4 \\
\hline Pinularia & 14 & 0.5 & 17 & 2.2 \\
\hline Sururella & --- & --- & 18 & 0.7 \\
\hline Synedra & --- & --- & 9 & 0.5 \\
\hline \multicolumn{5}{|l|}{ Euglenophyceae } \\
\hline Phacus & 14 & 1.5 & 17 & 1.6 \\
\hline Euglena & 12 & 0.9 & 15 & 0.7 \\
\hline
\end{tabular}

Heavy metals concentrations and distribution in E. crassipes: Concentrations of alkali, alkaline earth and heavy metals from different parts leaf, stem and root of E. crassipes samples collected from the littoral region of Lake tana are given in Figure 2. Alkali (K) and earth alkaline $(\mathrm{Ca}$ and $\mathrm{Mg})$ showed statistically significant differences $(p<0.05$; Tukey test) between roots stem and leaf parts. The order of abundance of $\mathrm{Ca}, \mathrm{Mg}$ and $\mathrm{K}$ was root $>$ stem $>$ leaf. Distributions of heavy metals in the root, stem and leaf of water hyacinth followed similar trend as of cations where higher concentrations were noted in the root $>$ stem $>$ leaf (Figure 3). There was no significant difference ( $p$ $>0.05)$ in the distributions of $\mathrm{Cd}, \mathrm{Cr}$ and $\mathrm{Pb}$ between macrophyte parts. As an important component of aquatic systems, macrophytes play a significant role in biological filtration of water (Admas et al., 2017). Furthermore, positive advantages of aquatic macrophytes include their potential to accumulate excess chemicals and heavy metals in their plant body (Kabeer et al., 2013). In consensus to previous reports that described root as primary site of accumulation for heavy metals in E. crassipes, the finding of the present study also revealed root as the primary site of accumulation. This may be due to over accumulation of metals caused by prolonged low-level exposure of roots (Jones et al., 2018).

Factors that affect metal accumulation in aquatic macrophytes, includes variation in plant species, growth stage, physiological adaptations and demand for absorption are among the major once (Jones et al., 2018). The abundance pattern of heavy metals in $E$. crassipes samples were in the order $\mathrm{Cu}>\mathrm{Zn}>\mathrm{Cr}>\mathrm{Pb}$ $>\mathrm{Cd}$ in the root, stem and leaves. Aquatic macrophytes absorb heavy metals from water and make their internal concentration several fold greater than the surrounding environment (Jones et al., 2018).

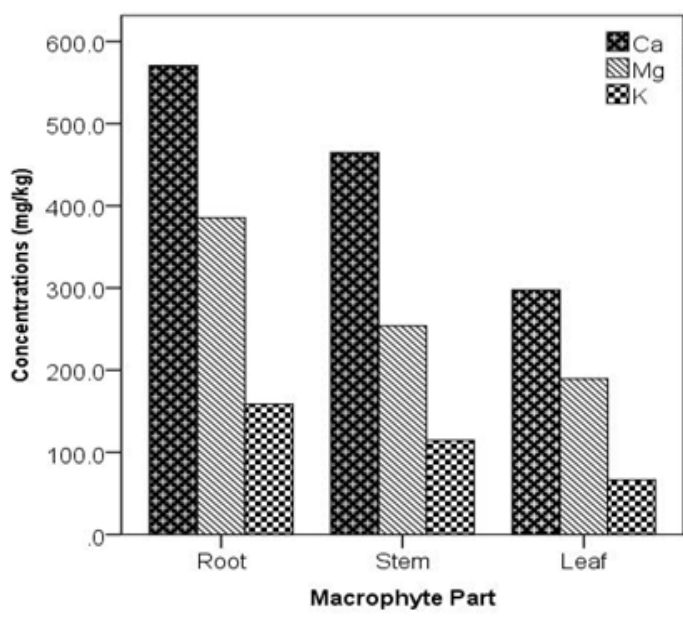

Fig 2. Concentrations $\left(\mathrm{mg} \mathrm{kg}^{-1}\right)$ of alkaline $(\mathrm{K})$ and earth alkaline (Ca and $\mathrm{Mg}$ ) metals from $E$. crassipes parts

Socio-economic impacts of water hyacinth: There is a contradiction on the socio-economic impacts of water hyacinth where some consider the macrophyte has a positive impact benefiting both the society and the ecology; while others contemplate the species has a negative impact that cause societal and ecological problems leading to ecosystem deterioration. Results from the survey study indicated about $84 \%$ of the respondents argued that water hyacinth infestation in and around Lake Tana catchment has a negative impact while the remaining $16 \%$ of respondents agreed on the positive impacts of the macrophyte. The most frequently mentioned negative impacts include that water hyacinth infestation created a favourable environment for breeding of many vectors such as mosquito of malaria, snail host of schistosomiasis, filariasis. The current finding corroborates with the finding of Chapungu et al. (2018), from Zimbabwe who reported similar opinion of respondents against malaria. 


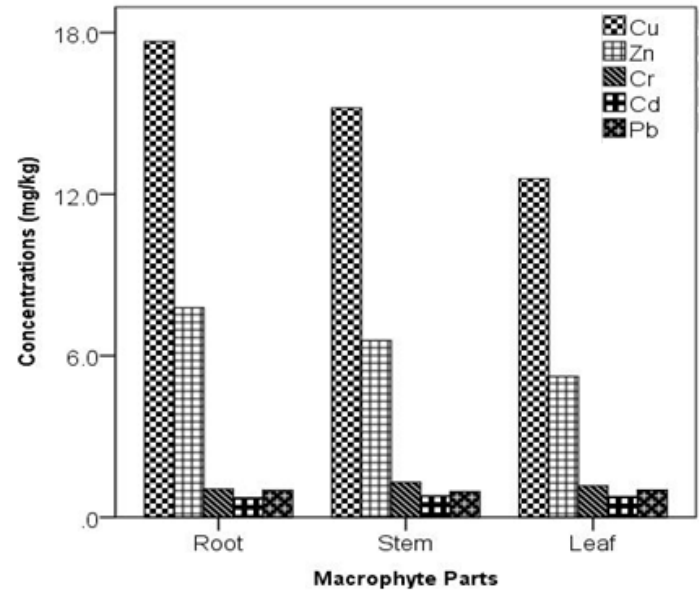

Fig 3. Concentrations of Heavy metals $\left(\mathrm{mg} \mathrm{kg}^{-1}\right)$ from different parts of E. crassipes

The other most negative socio-economic impact of water hyacinth in Lake Tana catchment is access to boat transport, fishing and navigation. About $96 \%$ of the respondents claimed that they face a serious problem to travel from place to place as the infestation of the macrophyte becomes a barrier for boat transport and even it damages their engine. Similarly, they have also faced economical problem due to a significant decline in the total fish catch (Enyew et al., 2020). Villamagna and Murphy (2010), elaborated the huge infestation of water hyacinth denied access to fishing grounds. The dens mat cover together with the root system destructed breeding and nursery grounds of many commercially important fishes. Kateregga and Sterner (2009), disclosed the decreased catch rates and increased effort of fishing in Lake Victoria due to the blocked access to fishing by water hyacinth. Decreased recreational and aesthetic value are also among the major societal problems caused by water hyacinth. In the present study, about $78 \%$ of the respondents indicated that infestation of the macrophyte reduced the aesthetic value of the lake while the remaining $28 \%$ argued the macrophyte and the inflorescence of flowers from it increased the aesthetic value of the Lake. However, majority of the respondents together argued that water hyacinth infestation severely affect recreational value of the lake as someone cannot easily swim in the lake. The finding of the present study is in line with the findings of (Kateregga and Sterner, 2009; Villamagna and Murphy, 2010; Chapungu et al., 2018). Huge water hyacinth infestation in and around the catchment of aquatic systems most importantly affects good water quality and food security. About $56 \%$ of respondents argued that water hyacinth has a positive impact in relation to water pollution as it is a best phytoremediator which can absorb many pollutants and toxic metals in the water. The macrophyte also facilitate sedimentation of clay particles and provides debris free clear water. However, the dense coverage becomes a barrier to access water for domestic use and animal watering. On the other hand, about $44 \%$ of respondents claimed the opportunistic nature of the macrophyte (where it can float in the open water and found rooted in the shallower part of the lake) is a threat for food security as it is currently invading the shore of Lake Tana and showing a gradual encroachment to agricultural lands.

Conclusions: Water hyacinth has a dichotomous impact on the physico-chemical water quality parameters. However, the impact is harmful on the socio-ecological aspect. In Lake Tana catchment, the huge infestation of water hyacinth seriously affects the abundance and occurrence of phytoplankton which can lead to biodiversity loss. The species can be used as an effective phytoremediator in polluted aquatic systems. Root of water hyacinth is a hyper accumulator of heavy metals and cations than stem and leaf. Generally, water hyacinth macrophyte has an impact on society as well on the ecology of Lake Tana.

Acknowledgment: The author is thankful to University of Gondar, Department of Biology and Abay Basin research laboratories for permitting to use their laboratories. The author is also thankful to Lidiya Tesfaye for her assistance during laboratory work.

\section{REFERENCES}

Abebe, E; and Kebede, A (2017). Assessment of Climate Change Impacts on the Water Resources of Megech River Catchment, Abbay Basin, Ethiopia. Open J. of Modern Hydrology. 7: 141152

Admas, A; Sahle, S; Belete, E; Agidie, A; Alebachew, M (2017). Controlling Water Hyacinth in Lake Tana Using Biological Method at Green House and Pond Level. European J. Exp. Biol. 7(5): 29

Akale, AT; Moges, MA; Dagnew, DC; Tilahun, SA; Steenhuis, TS (2018). Assessment of Nitrate in Wells and springs in the North Central Ethiopian Highlands. Water. 10: 476

American Public Health Association (APHA), American Water Works Association, and Water Pollution Control Federation (1999). Standard methods for the examination of water and wastewater $\left(20^{\text {th }}\right.$ edd.): Washington, D.C.

Chapungu, L; Mudyazhezha, OC; Mudzengi, B (2018). Socio-ecological Impacts of Water 
Hyacinth (Eichhornia Crassipes) Under Dry Climatic Conditions: The Case of Shagashe River in Masvingo, Zimbabwe. J. Environ. Sci. and Public Health 2: 36-52

Dersseh, MG; Kibret, AA; Tilahun, SA; Worqlul, AW; Moges, MA; Dagnew, DC; Abebe, WB; Melesse, AM (2019). Potential of Water Hyacinth Infestation on Lake Tana, Ethiopia: A Prediction Using a GIS-Based Multi-Criteria Technique. Water. 11: 1921

Dersseh, MG; Tilahun, SA; Worqlul, AW; Moges, MA; Abebe, WB; Mhiret, DA; Melesse, AM (2020). Spatial and Temporal Dynamics of Water Hyacinth and Its Linkage with Lake-Level Fluctuation: Lake Tana, a Sub-Humid Region of the Ethiopian Highlands. Water. 12: 1435

DiTomaso, JM; Kyser, GB; Oneto, SR; Wilson, RG; Orloff, SB; Anderson, LW; Wright, SD; Roncoroni, JA; Miller, TL; Prather, TS; Ransom, C; Beck, KG; Duncan, C; Wilson, KA; Mann, JJ (2013). Weed control in natural areas in the Western United States. Weed Research and Information Center. University of California, $544 \mathrm{pp}$

Engdaw, F (2014). Morphometric relations, diet composition and ontogenetic dietary shift of Labeobarbus intermedius (Rüppell, 1836) in Lake Tana gulf of Gorgora, Ethiopia. Int. J. Fish. Aquac. 6(11): 124-132

Engdaw, F; Subramanian, C (2015). Species Composition and Abundance of Phytoplankton Communities in relation to Physicochemical Parameters of Lake Tana at Gulf of Bahir Dar, Ethiopia. Appl. Biol. and Biotech. 3(1): 10-15.

Enyew, BG; Assefa, WW; Gezie, A (2020). Socioeconomic effects of water hyacinth (Echhornia Crassipes) in Lake Tana, North Western Ethiopia. PLoS ONE 15(9): e0237668

Gao, YN; Dong, J; Fu, QQ; Wang, YP; Chen, CJ; Li, H; Li, R; Zhou, CJ (2017). Allelopathic effects of submerged macrophytes on phytoplankton. Allelopathy Journal. 40(1): 01-22

Gebremedhin, S; Getahun, A; Anteneh, A; Bruneel, S; Goethals, P (2018). A Drivers-Pressure-StateImpact-Responses Framework to Support the Sustainability of Fish and Fisheries in Lake Tana, Ethiopia. Sustainability. 10: 2957
Gerhardt, S; Boos, K; Schink, B (2010). Uptake and release of phosphate by littoral sediment of a freshwater lake under the influence of light or mechanical perturbation. J. Limnol. 69(1): 54-63

Goshu, G; Aynalem, S (2017). Problem Overview of the Lake Tana Basin. Social and Ecol. Sys. Dynamics. $\quad 9(23)$ : doi: https://doi.org/10.1007/978-3-319-45755-0_2

Hellmann, JJ; Byers, JE; Bierwagen, BG; Dukes, JS (2007). Five potential consequences of climate change for invasive species. Conservation Biol. 22(3): 534-543

Hou, D; He, J; Lü, C; Sun, Y; Zhang, F; Otgonbayar, $\mathrm{K}$ (2013). Effects of environmental factors on nutrients release at sediment-water interface and assessment of trophic status for a typical shallow Lake, Northwest China. The Sci. World J. 1-16

Jones, JL; Jenkins, RO; Haris, PI (2018). Extending the geographic reach of the water hyacinth plant in removal of heavy metals from a temperate Northern Hemisphere river. Scientific Reports. 8: 11071

Kabeer, R; Varghese, R; Jaysooryan, KK; George, J; Ambily, V; Sylas, VP (2013). Removal of zinc lead and cadmium by water hyacinth ( $E$. crassipes). Int. J. Curr. Res. 5(9): 2506-2509.

Kateregga, E; Sterner, T (2009) Lake Victoria fish stocks and the effects of water hyacinth. $J$. Environ. Develop. 18: 62-78

Li, H; Shi, A; Li, M; Zhang, X (2013). Effect of pH, Temperature, Dissolved Oxygen, and Flow Rate of Overlying Water on Heavy Metals Release from Storm Sewer Sediments. J. Chem. 2013:111

Rahel, FJ; Olden, JD (2008). Assessing the effects of climate change on aquatic invasive species. Conservation Biol. 22: 521-533.

Sarneel, JM; Geurts, JJM; Beltman, B; Lamers, LPM; Nijzink, MM; Soons, MB; Verhoeven, JTA (2010). The effect of nutrient enrichment of either the bank or the surface water on shoreline vegetation and decomposition. Ecosystems. 13: 1275-1286

Strokal, M., Kroeze, C., Wang, M., Bai, Z. and Ma, L. (2016). The MARINA model (Model to Assess River Inputs of Nutrients to seas. Model 
description and results for China. Sci. Total. Environ. 562: 869-888.

Tarekgne, W; Ayalew, W; Minwyelet, M; Jacobus, V (2012). Seasonality in Abundance, Biomass and Production of the Phytoplankton of Welala and Shesher Wetlands, Lake Tana Sub-Basin (Ethiopia). J. Water Resource and Protection. 4: 877-884

Tibebe, D; Zewge, F; Lemma, B; Kassa, Y; Bhaskarwar, AN (2018). External Nutrient Load and Determination of the Trophic Status of Lake Ziway. CSVTU Int. J. Biotech. Bioinfor. Biomed. 3(2): $01-16$

USEPA, United Stated Environmental Protection Agency (2011). National Primary Drinking Water

Regulations. http://water.epa.gov/drink/contami nants/index.cfm

Villamagna, AM; Murphy, BR (2010). Ecological and socio-economic impacts of invasive water hyacinth (Eichhornia crassipes): a review. Freshwater Biol. 55: 282-298

WHO, World Health Organization (2011). Guidelines for drinking water quality (4th Ed). Geneva, Switzerland.
Wondie, A; Mengistou, S; Vijverberg, J; Dejen, E (2007). Seasonal variation in primary production of a high-altitude tropical lake (Lake Tana, Ethiopia): effects of nutrient availability and water transparency. Aquat. Ecol. 41: 195-207

Wondie, A; Seid, A; Molla, E; Goshu, G; Gebrekidan, WG; Shibabaw, A; Tewabe, D; Genanew, M (2012). Preliminary Assessment of Water hyacinth (Eichornia crassipes) in Lake Tana. Proceedings of National Workshop Biol. Soc. Ethiop. Addis Ababa.

Wondim, YK (2016). Water Quality Status of Lake Tana, Ethiopia.Civil and Environ. Res. 8(9): 3941.

Worku, M; ahile, S (2018). Impact of Water Hyacinth, Eichhornia crassipes (Martius) (Pontederiaceae) in Lake Tana Ethiopia: A Review. J. Aquac. Res. Develop. 9: 520

Yifru, F; Abera, T; Tariku, T; Taye, T (2007). Distribution, impact and management of water hyacinth at Wonji-Shoa sugar factory. Ethiop. J. Weed Manage. 1: 41-52 